\title{
Affordable Housing Reimagined
}

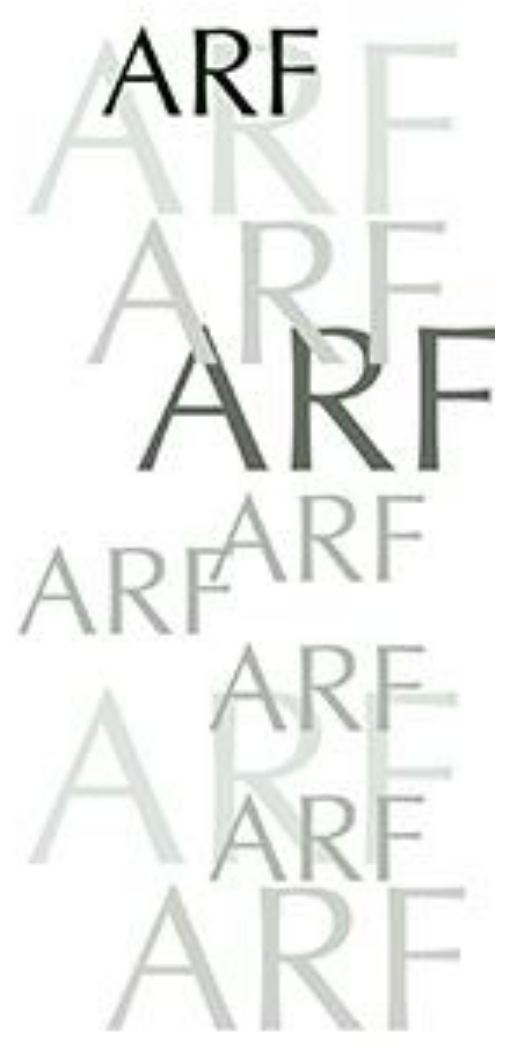

In search of the neighbourly, spacious and rebuildable

\author{
Michael Asgaard Andersen \\ The Royal Danish Academy \\ masg@kglakademi.dk
}

\begin{abstract}
This paper explores contemporary affordable housing in Denmark. The aim is to unfold central ideas in some of the most progressive projects that have recently been designed and built. The paper goes into three areas of architecture, namely the social, the formal and the technological. In each area one aspect is analysed and discussed with a point of departure in a specific project: The social in relation to the neighbourly and The Orient by Dorte Mandrup, the formal in relation to the spacious and Dortheavej housing by BIG, and the technological in relation to the rebuildable and Circle House by Fællestegnestuen. The aim is to contribute to the current discourse on affordable housing from a Danish standpoint and in an architectural perspective.
\end{abstract}

Keywords: Affordable housing, community, neighbourliness, spaciousness, design for disassembly, design for maintenance, circular economy, BIG, Dorte Mandrup, 3XN/GXN, Vandkunsten, Lendager Group

\section{Introduction}

It is from a privileged position that affordable housing is currently being developed and built in Denmark. This is not least due to the significant role affordable housing has played in Danish architecture since the 1930s, including projects designed by prominent twentieth century architects like Kay Fisker, C.F. Møller and Steen Eiler Rasmussen (Bendsen, 2012; Bech-Danielsen \& Christensen, 2017). There is a strong tradition for sound and functional homes inhabited by people from different social strata and income groups. But there are also conditions that make it hard to continue building affordable housing to the same standards they used to have. Apart from high land value and building costs, which are among the highest in Europe (Andersen, 2007), the strict legislation plays a pivotal role in the development of affordable housing (Meden \& Hansen, 2019), and generally it seems difficult to develop new ways of building and living within this sector of housing. Affordable housing is often considered and judged from a political and economic perspective, and in the Danish media it is often discussed in relation to so-called ghettoes, even though they only cover a relatively small part of it (BL 2018, 7-10). There are, of course, multiple ways of considering affordable housing, and this paper aims at approaching affordable housing by considering three contemporary themes from an architectural perspective.

A number of recent Danish projects show new ideas and rediscover old ideas in affordable housing, and many of them can roughly be grouped into three intertwined fields in architecture, namely the social, formal and technological. While they are uniquely expressed in each of the projects, the ideas within each field also have a lot in common. Based on an analysis and discussion of three projects that have recently been built or are in the process of being built by leading Danish architectural offices, how might affordable housing in Denmark 


\section{The spacious: housing on Dortheavej}

Danish legislation sets up strict rules for affordable housing, not only when it comes to ownership and financing, but also regarding size and rent (Transport-, Bygnings- og Boligministeriet, 2019). In addition to the economic limits, which are themselves a challenge, it is often the limited size of the apartments that drives the spatial organization in affordable housing. However, there are also less defined conditions in the legislation which make it possible to deviate from the standard.

From reviews in Danish medias, it is evident what is at stake in the affordable housing on Dortheavej in Copenhagen, designed by BIG Bjarke Ingels Group. It is a long building in mostly five stories that faces the street and has a concave shape at the middle, where a passage leads to the courtyard and further on to an open gate in the next block. The building is constructed from prefabricated roomsized concrete units, which are stacked and staggered. On the exterior, the units are covered with vertical and horizontal boards, and the interiors have wood flooring, plaster walls, and raw concrete ceilings.

Karsten R.S. Ifversen, a critic writing for Politiken, was very excited about the building, announcing in the headline that he would "like to move in" (Ifversen $2018,4)$. This was followed up by stating that the apartments are "some of the most attractive urban, affordable housing. There is a great deal of inventiveness and a clear idea, which has been carried entirely through. It is excellent" (Ifversen 2018 , 4). Fully aware of the commonly voiced opinion that BIG's projects are formalistic and driven by a desire to create shocking effects, he believes that in this building, "it is not something external, a simple figure without meaning, it is real qualities" (Ifversen 2018, 5). It was also with excitement that Anne Pind in an almost lyrical prose reviewed the building in the Danish Association of Architects' magazine Arkitekten under the headline "Dortheavej: Højt til Loftet" [Dortheavej: A Building with a High Ceiling] (Pind, 2018). The phrase "a high ceiling" has transferred meanings as it can be understood as "a lot of space and fresh air" and "freedom and openness" (Ordnet, 2019). These are the values that she writes into the built form. Yet, it is a delicate question whether the building promotes "freedom and openness" in a neighbourhood, which is notoriously known for its crime and gang violence. She aims to provide some sort of answer to this question by describing how the building engages in the surroundings by establishing a passage for a shortcut to the next street, but one might wonder if that is a sufficient response to the tough challenges of the place. Torben Weirup, a critic writing for Berlingske, in his review compared the building to affordable housing from the 1930s and 40s with the telling headline "En renæssance for socialt boligbyggeri?" [A renaissance for affordable housing] (Weirup, 2018). The compliment is supposed to signal a comeback for affordable housing of high architectural quality. Weirup understands the building as part of a gentrification, which he considers to be positive. While less crime and gang violence clearly are so, gentrification is rarely seen as the right way to achieve this, as it pushes the low-income groups and socially vulnerable further away from the city centre.

Each of the three critics sees the affordable housing on Dortheavej as an architectural success, because BIG has created spacious apartments on a limited budget and for a low rent, within a very restricted field of possibilities (Ifversen, 2018; Pind, 2018; Weirup, 2018). By thoroughly searching for the possibilities in the regulations of affordable housing, BIG has found part of their answer to the design of the building and with that challenged the conventional understanding of this type. What makes it stand out is in part that all apartments have a room with 3.5-meter ceiling height, which was common in large, old bourgeois apartments, but very rare in new apartments. While there are size restrictions on the floor area, there are none on the ceiling height, so even though the apartments are rather small, they appear spacious due to the height of the main 
room. As the critics cherish the spaciousness of these rooms and the way the building differentiates itself from others, they seem to overlook some of the implications of this.

In Denmark, as in many other places, urban housing has traditionally had an anonymous exterior, withdrawing attention in its context. Throughout the twentieth century, housing has served as a visual backdrop for institutions and monuments of the city as well as for the life taking place on streets and squares, paying respect to the common. However, in recent decades this has changed as mainstream housing has become more spectacular, drawing further attention. The affordable housing on Dortheavej belongs to this category, as does most of the architecture by BIG. It stands out, rather than blends in, and as such it is very different from Mandrup's The Orient. When standing out becomes the norm in housing, as is the case in the aforementioned places in Copenhagen, a neighbourhood can easily lose not only its architectural coherence, but also its social cohesion (Jensen, Schmidt \& Vitus 2019, chapter 3 \& 5).

It raises a difficult
question with two
seemingly
incomparable
aspects, namely if
the resources spent
on construction and
use outweighs the
possible increase in
quality of life that
the spaciousness
provides?

New buildings are so effectively insulated that the greatest impact on Danish housing, when it comes to saving energy and material resources, can be achieved by working with the production and construction phase. The affordable housing on Dortheavej has a compact volume with many shared walls and floors as well as staggered rooms with a 3.5 metre floor-to-ceiling height, which required more material and energy to build than the continuous 2.5 metre standard floors. On an everyday basis in Denmark, an increase in ceiling height will also mean an increase in energy use to heat up the rooms in the winter. No tests or measurements have been made so far in this affordable housing project, and it is outside the scope of my research to do so, but it is likely that the large southfacing glass panels will result in significant overheating in the summer, but reduce heating costs in the winter. From studies of similar buildings (Gutierrez et al., 2019), it is reasonable to assume that the overall use of energy and material resources is higher than the average apartment housing being built in Denmark these years. It raises a difficult question with two seemingly incomparable aspects, namely if the resources spent on construction and use outweighs the possible increase in quality of life that the spaciousness provides? Of course, it is not given that the additional sunlight, air and spaciousness will necessarily improve the inhabitants' quality of life, even if that is the aim, but one might wonder to what extent it can reduce ill-health.

\section{The rebuildable: Circle House}

Circular economy has received a lot of attention in Denmark, and among the most significant outcome is a report on Denmark by the Ellen MacArthur Foundation (MacArthur, 2015), an advisory board established by the government (Miljø- og Fødevareministeriet, 2017), and a number of initiatives by Realdania (Kleis, 2013; Sørensen \& Oberender, 2018), a large Danish association operating with the built environment.

Apart from the above publication by the Ellen MacArthur Foundation, some of the most influential publications for the development in Denmark have been Building a Circular Future by Kasper Guldager Jensen, 3XN/GXN, and John Sommer, MT Højgaard (Jensen \& Summer, 2016); Principles of Design for Deconstruction to Facilitate Reuse and Recycling, Bill Addis and Jørgen Schouten, (Addis \& Schouten, 2004); and Cradle to Cradle, Michael Braungarten and William MacDonough, the latter being translated into Danish (Braungarten \& MacDonough, 2009). The first in Denmark to comprehensively include some of these concepts in a larger complex was the architectural office of Vandkunsten, who applied them in their project for affordable housing in Lisbjerg Bakke, Aarhus. The complex is mainly built in prefabricated wood elements with a design 
project is to be able to remove the foundation from the ground, when the building is taken down, and use it in another project.

\section{One question not raised often enough is whether it might be a better solution to design for maintenance?}

The questions that these two proposals raise relate to broader aspects of design for disassembly. One question not raised often enough is whether it might be a better solution to design for maintenance? In the book Circle House, the question is addressed indirectly in one of the interviews, during which architect Søren Nielsen from Vandkunsten states: "We want the aesthetic appeal and functionality of our structures to ensure that no-one is going to tear them down, but if that does happen, and it does from time to time, then the assets will be dismantlable, and their constituent materials will be reusable or recyclable" (GXN \& Responsible Assets 2018, 22). But as recent research into LCC and LCA in Denmark shows (Sørensen et al., 2020; Jensen \& Birgisdottir, 2018), the relationship between disassembly and maintenance is far more complex than the book implies. Based on arguments for multifunctional use and a sharing economy (MacArthur 2015, 53-65), one can easily imagine how a building designed for maintenance can last and work well for a long time. This is not just a question of material resources but becomes one of energy resources, as the process of disand reassembly requires energy to dismantle, move, prepare and rebuild. In fact, one might read this into Nielsen's statement, when talking about the "functionality of our structures" and pointing to the "aesthetic appeal" as a reason to keep a building rather than dismantling it.

Another question that should also be raised more often is who will be reusing the building elements from today in fifty or a hundred years? If we think of the building technology that was used a century ago, few people would want to upcycle structural elements from that period in largescale projects today. Or think back on the chemicals used in the construction industry half a century ago and imagine how it would be perceived today, reusing building components from those years. Even if it is possible to map for example the structural properties of building elements through a 3D scanning, it does not change the legal and environmental expectations for contemporary components, which are obviously very different from earlier times. There is a good chance that in fifty or a hundred years, the building industry will look back at building elements from today with some concerns.

There are of course exceptions to this, and in Denmark a good example is bricks. In buildings from before 1960, lime mortar was used in the construction industry. When they are disassembled today, the bricks can be cleaned in a mechanical process without the use of chemicals (Gamle Mursten, 2019). Yet, bricks are mainly used today as part of the climate screen and rarely as the main structure, since the demand for insulation and structural properties in connection with fire have changed. There is little, if anything, suggesting that the development of building elements and structural systems will significantly slow down in the coming fifty or hundred years, and if the technological development continues at the same rate, or even faster, it seems unlikely that it would be attractive to upcycle building elements from today.

Nevertheless, with all the good intentions in the project, one might ask to what extent Circle House is scalable? It requires a critical mass to make upcycled building materials more than just a philanthropic enterprise. While the environmental benefits are obvious, there must be enough reusable building elements to have competitive stores and enough buyers to have a reasonable turnover rate in order to gain the commercial benefits. The issue of turnover rate is key, as the expenses for storing building elements can make the business unprofitable. Another issue, which is partially addressed by Jensen \& Sommer (Jensen \& Sommer, 2016), is the physical distances between the sites of disassembly, storage and reuse. Long distances mean more transport resulting in additional costs and possible pollution. These are not new problems, but are 
known today at a smaller scale in a business like genbyg.dk (Genbyg, 2019). Yet, they need to be addressed if design for disassembly is to work at a larger scale, both economically, environmentally and architecturally.

\section{At home in affordable housing}

The Orient by Dorte Mandrup, the housing on Dortheavej by BIG, and Circle House by Fællestegnestuen each respond to different challenges in contemporary affordable housing in Denmark. In The Orient, these are related to belonging, loneliness and neighbourliness; in the housing on Dortheavej to context, spaciousness and wellbeing; and in Circle House to reuse and long-term value. The challenges differ and so do the responses, which is among other places visible in the exterior expression. The common spaces in The Orient allow for a visual connection between the inhabitants, courtyard and street. While it exposes the inhabitants using the spaces, it also opens up the building to the neighbourhood and potentially extends a sense of neighbourliness into the surroundings. The large glass panels in the housing on Dortheavej are in every apartment, as it is also known from the office's VM Houses and several of their other housing projects, and they expose the inhabitants in their private settings. This creates a lesser differentiation between private and public, while furthering the sense of spaciousness. The intention in Circle House is to express the reusable character of the materials in an almost explanatory way, which supports the office's fascination with circular economy. Yet, despite the very different architectural expressions, they all three showcase their main intention in the exterior.

Each of the architects addresses a challenge within the realm of affordable housing. For Dorte Mandrup it lies within the social realm, when she explores the shared spaces and interactions between the inhabitants. One could imagine a further exploration of shared spaces, learning not least from the long and rich tradition of Danish cohousing (Vedel-Petersen, Jantzen \& Ranten, 1988; McCamant \& Durant, 1988), where the inhabitants have developed multiple ways of sharing space, time and stuff (Andersen, 2020). It is an important challenge that Mandrup is addressing, as it has broader relevance for the social problems that Danish society is facing today. These include not just loneliness and the health problems related hereto, but also the increasing inequality with all its societal effects. In continuation of the explorations into modes of sharing, one could also imagine a rethinking of the notions and relations between the individual and the common. Again, Danish cohousing could serve as a model where they are not seen as oppositions to one another, and where notions of semi-individual and semi-common provide a more nuanced mode of understanding.

For BIG the challenge within affordable housing is in the realm of space and form, where they explore new possibilities. The limitations on the size of affordable housing makes the spatial configuration and spaciousness important. At its best, this attention can be a way of reducing the use of resources, as it is seen in compact living (Nelson, 2018). But that is not the case in the housing at Dortheavej. Rather, it seems that the eagerness to design a novel, eye-catching building has been more important. The balance between the spatial qualities of everyday life on one hand and the construction and maintenance costs on the other is by no means simple. As they are difficult to compare and weight up against one another, there is no easy answer to this, and it is exactly this problem that BIG's affordable housing is pointing out. 
To point to design

for maintenance [...] is here suggested as a way to further develop the relations between reusable materials from disassembled buildings and the construction of new ones, however long they stand.
For 3XN/GXN, Lendager Group and Vandkunsten, it is within the technical realm that they explore possible ways of reusing materials to lower the environmental footprint. The problem of resource overuse evidently extends far beyond affordable housing, and it is all the more notable that the challenge is being addressed in this inexpensive housing type. Yet, it could become a problem if design for disassembly is used for the purpose of building affordable housing that only lasts for half a century, not knowing what to do with the materials afterwards. In that case, design for disassembly is used as an excuse to construct in poor quality. To point to design for maintenance is not to suggest a return to how things were or a status quo. On the contrary, it is here suggested as a way to further develop the relations between reusable materials from disassembled buildings and the construction of new ones, however long they stand. Currently, new calculation tools are being developed for LCC and LCA (Birgisdottir et al., 2019; Birgisdottir \& Rasmussen, 2019), which will make it possible to better understand and act on the implications of contemporary mainstream construction and design for disassembly. This should allow for a more thorough design methodology when using existing building material and making new ones.

While each of the projects addresses a particular challenge, The Orient takes it even further, as it is expected to be DGNB-certified. This is a significant step in the direction of affordable housing dealing with a range of sustainable aims. Because, however important each of these challenges are, it is important to see them as part of a whole.

The UN's Sustainable Development Goals have many implications, one of them is that we should not optimize one of them without considering the consequences for the others. While shared space, spacious rooms and design for disassembly are fine in their own right, they should also be seen in a larger context. In other words, we need to consider social, formal and technological problems as part of the same challenge, and each housing project as a possible contribution to the overall goals. None of the three projects sufficiently addresses both social, formal and technological challenges in their design, which is not unusual today. Yet, housing, and more generally architecture, has the ability to incorporate all of these and more challenges into the design. This might not only result in more adequate contemporary housing, but also in novel architectural expressions. New and old materials combined as well as new modes of constructing and joining could allow for exciting architectural explorations. This is already visible in other housing projects that aspire to a circular way of thinking, such as the Resource Rows by Lendager Group (Lendager \& Vind 2018, 65-71), and one can only dream of what this will do to our experience of living in cities.

The Circle House Lab has been established as a continuation of the Circle House project. The lab includes more than eighty organisations, and the aim is to explore "future standards for circular construction" (Bloxhub, 2019). With so-called laboratory days, green papers and a yearly summit, the purpose is to develop these standards. It is intended to take place within "six central themes for circular economy, such as building passport, waste management, takeback arrangements, design for disassembly and selective dismantling" (Bloxhub, 2019). The initiative shows how the interest in circular economy continues to expand and evolve, but also the need for more academic research in this field. There are similar initiatives in other countries, and even if some of the thoughts seem far from contemporary practices, one can hope that it will affect the building industry at large.

Although one can be critical of various issues in these projects, there is also reason to be appreciative. It is admirable that leading architectural offices take on the challenge to design the most restricted and inexpensive housing in Denmark. The offices have taken a social, formal or technical challenge a step further in their project, which can be of inspiration to others within the field of

PEER-REVIEWED ARTICLE 
affordable housing, either as a direct approach or as an encouragement to be more explorative. It is also remarkable that it is within a field with many restrictions and limited budgets that significant aspects of the development in Denmark is taking place. This shows a broader commitment among the affordable housing organisations to contribute not only with socially sustainable solutions by providing homes for many, but also to the broader sustainable transition in the building industry and, potentially, in our way of living. As such, the three projects can be seen as significant steps on the way to developing sustainable affordable housing. A next step might be to integrate social, formal and technical challenges more in order to obtain a more comprehensive architecture. In this way, affordable housing could be a role model for other kinds of housing and new ways of being at home in the city.

\section{Acknowledgements}

The author would like to thank the organizers of The 11th Annual Symposium of Architectural Research: Architecture and City as a Home for the opportunity to make a presentation with the initial ideas for this paper as well as the management at Aarhus School of Architecture for initiating this research into affordable housing.

\section{References}

Addis, B. \& Schouten, J. 2004. Principles of Design for Deconstruction to Facilitate Reuse and Recycling. London: Ciria [Report C607]

Andersen, U. 2007. "Danske boligbyggerier er Europas næstdyreste". Available through: https://ing.dk/artikel/danske-boligbyggerier-er-europas-naestdyreste81524 [Accessed 10 September 2019]

Andersen, M. A. (2020). "Lektor i arkitektur: Vandkunstens fuckfinger til arkitektstanden har gjort os bedre til at dele" Available through: https://politikenbyrum.dk/Nyheder/art7804176/Vandkunstens-fuckfinger-tilarkitektstanden-har-gjort-os-bedre-til-at-dele [Accessed 29 May 2020]

Arnfred, T. 1998. Fællestegnestuen - et arkitektværksted. Copenhagen: Arkitektens Forlag

Bech-Danielsen, C. \& Christensen, G. 2017. Boligområder i Bevægelse. Copenhagen: Landsbyggefonden

Bendsen, J. R. 2012. Danmarks Almene Boliger. Copenhagen: Dansk Arkitektur Center

Birgisdottir, H., Kanafani, K., Zimmermann, R. K., Andersen, C. M. E., Hatic, D., Elmbæk, M., Kamper, M., Falbe-Hansen, M. \& Torsten Sack-Nielsen, T. 2019. Dialogværktøj: Cirkulær værdiskabelse i den eksisterende bygningsmasse

Birgisdottir, H. \& Rasmussen, F. N. 2019. "Development of LCAbyg: A National Life Cycle Assessment Tool for Buildings in Denmark" in IOP Conf. Ser.: Earth Environ. Sci. 290

Bloxhub 2019, "Circle House Lab". Available through: Bloxhub webpage https://bloxhub.org/circlehouselab/ [Accessed 20 November 2019]

Braungarten M. \& MacDonough W. 2009 (orig. 2002), Cradle to Cradle. Rigdom og vækst uden affald: En banebrydende vision for det 21. århundrede. Copenhagen: Nyt Nordisk Forlag 
BL Danmarks Almene Boliger 2015. Urbanisering og Sammenhængskræft. Available through: BL Danmarks Almene Boliger website http://www.epages.dk/bl/312/ [Accessed 10 September 2019]

BL Danmarks Almene Boliger 2018. De 16 'hårdeste ghettoområder'. Available through: BL Danmarks Almene Boliger website

https://bl.dk/media/1491/ghettorapport-oktober-2018-web.pdf [Accessed 8 September 2020]

BL Danmarks Almene Boliger 2019. "The Danish Social Housing Sector". Available through: https://bl.dk/in-english/ [Accessed 8 September 2020]

BL Danmarks Almene Boliger 2020. "Hvad er en Almen Bolig?". Available through: https://bl.dk/politik-og-analyser/temaer/hvad-er-en-almen-bolig/ [Accessed 10 September 2020]

Boliga 2017. "Vild luksus: Her er Danmarks dyreste lejligheder". Available through: https://www.boliga.dk/artikel/vild-luksus-her-er-danmarks-dyrestelejligheder [Accessed 20 November 2019]

Gamle Mursten 2019, "Om Gamle Mursten". Available through: Gamle Mursten webpage http://gamlemursten.dk/om-gamle-mursten/ [Accessed 4 December 2019]

Genbyg 2019, "Hvem er vi". Available through: Genbyg webpage https://genbyg.dk/hvem-er-vi/ [Accessed 4 December 2019]

Gutierrez, M. S. M., Mørck, O., Thomsen, K. E., Wittchen, K. B., Illner, M., Erhorn-Kluttig, H., Erhorn, H., Mattoni, B., Zinzi, M., Jaćimović, M., Zavrl, M. Š. 2019. Life cycle assessment of typical multi-family houses with different energy performance levels

GXN \& Responsible Assets. 2018, Circle House: Danmarks første cirkulære boligbyggeri. Copenhagen

Jensen, J. O. \& Stensgaard A. G. 2016. Evaluering af AlmenBolig+. Copenhagen: Statens Byggeforskningsinstitut

Jensen, K. G. \& Sommer, J. 2016, Building a Circular Future. Available through: 3XN/GXN webpage https://gxn.3xn.com [Accessed 6 June 2016]

Jensen. K. G. \& Birgisdottir, H. 2018. Guide to sustainable building certifications. Copenhagen: $\mathrm{SBi}$

Jensen, T. G., Schmidt, G. \& Vitus, K. 2019. Social sammenhængskraft. Begreb og virkelighed. Copenhagen: Samfundslitteratur

Ifversen, K. R. S. 2018, "Nordvest har fået en spritny almen boligblok, jeg gerne vil flytte ind i", Politiken, 12 May, pp.4-5 (Kultur)

Kleis, B. 2013. Upcycle House. Genbrug fra inderst til yderst. Copenhagen: Realdania Byg

Lejerbo, 2019. "Om Circle House" Available through: https://www.lejerbo.dk/omlejerbo/byggeri/circle-house [Accessed 27 August 2019]

Lendager, A. \& Lysgaard Vind, D. 2018, A Changemaker's Guide to the Future. Copenhagen: Lendager Group 
MacArthur Foundation, E. 2015, Potential for Denmark as a Circular Economy. A case study from: delivering the circular economy - a toolkit for policy makers, Available through:

https://www.ellenmacarthurfoundation.org/assets/downloads/20151113_Denma rkCaseStudy_FINALv02.pdf [Accessed 4 June 2018]

Mandrup, D. 2018, “Arkitekt: I Danmark er de almene boliger ikke almene. De er nedprioriterede boliger" [Architect: In Denmark affordable housing is not public. They are underprioritized housing], Politiken, 18 June. Available through: https://politiken.dk/debat/debatindlaeg/art6590825/I-Danmark-er-de-almeneboliger-ikke-almene.-De-er-nedprioriterede-boliger [Accessed 19 June 2018]

McCamant, K. \& Durant, C. 1988. Cohousing: A contemporary approach to housing ourselves. Berkeley, CA: Habitat Press

Meden, H. \& Hansen, M. A. V. 2019. Lærebog om almene boliger. domea.dk

Miljø- og Fødevareministeriet, 2017. Advisory Board for cirkulær økonomi: Anbefalinger til regeringen

Mortensen, P. D. 2018. Homes. Ensembles City. Housing and welfare in Copenhagen. Copenhagen: Architectural Publisher B

Møller-Jensen, V., Arnfred T. \& Sørensen J. O. 1978. Fællestegnestuen. Copenhagen: Fællestegnestuen

Nielsen, S. 2018, "Circle House - fra hype til handling". Available through: https://arkitektforeningen.dk/artikel/nyheder/circle-house-fra-hype-til-handling [Accessed 18 May 2018)

Nelson, A. 2018. Small is Necessary: Shared living on a shared planet. London: Pluto Press

Ordnet 2019, "højt til loftet (og vidt til væggene)". Available through: https://ordnet.dk/d do/ordbog?query=h\%C3\%B8jt\%20til\%20loftet [Accessed 6 December 2019]

Pind, A. 2018, "Dortheavej: Højt til Loftet", Arkitekten, no. 10. Available through: https://arkitektforeningen.dk/arkitekten/dorteavej-hojt-til-loftet/ [Accessed 27 August 2019]

Sørensen, S. Y., Oberender, A. 2019. Bygherrers rolle i den cirkulære økonomi. Taastrup: Teknologisk Institut

Sørensen, N. L., Rasmussen, F. N., Øien, T. B. \& Frandsen, A. K. 2020. "Holistic sustainability: Advancing interdisciplinary building design through tools and data in Denmark" in Construction Economics and Building

Transport-, Bygnings- og Boligministeriet 2019. "Almenboligloven". Available through: https://www.retsinformation.dk/Forms/R0710.aspx?id=206725 [Accessed 4 December 2019]

Vandkunsten, 2018. "Fremtidens Bæredygtige Almene Bolig er hybrid" Available through: http://vandkunsten.com/ [Accessed 31 July 2018]

Vedel-Petersen, F., Jantzen, E., \& Ranten, K. 1988. Bofællesskaber: En eksempelsamling. Hørsholm: Statens Byggeforskningsinstitut 
Vestergaard, H. 2016. "Almennyttige boliger" Available through:

https://denstoredanske.lex.dk/almennyttige_boliger [Accessed 2 September 2020]

Weirup, T. 2018, “En renæssance for socialt boligbyggeri?", Berlingske, 22 May, pp.4-5 (3. sektion)

ÆEldre Sagen, 2019. "Ensomhed. Ingen ældre skal føle sig ensomme”. Available through: https://www.aeldresagen.dk/presse/maerkesager/ensomhed [Accessed 18 October 2019] 